\title{
Effect of Dietary Marula Nut Meal on Liver Lipid Content and Surrogate Markers of Liver and Kidney Function of Broiler and Layer Japanese Quail
}

Bulelani Elvis Mazizi ( $\sim$ elvismazizi@gmail.com )

University of the Witwatersrand Faculty of Health Sciences https://orcid.org/0000-0002-7408-488X

Kennedy Honey Erlwanger

University of the Witwatersrand

Eliton Chivandi

University of the Witwatersrand

\section{Research Article}

Keywords: Non-conventional dietary protein, Cortunix cortunix japonica, circulating metabolites, liver and kidney health

Posted Date: January 6th, 2022

DOI: https://doi.org/10.21203/rs.3.rs-1155930/v1

License: (c) (i) This work is licensed under a Creative Commons Attribution 4.0 International License. Read Full License 


\section{Abstract}

Marula nut meal (MNM) can substitute soyabean meal (SBM) as a dietary protein source in Japanese quail diets without compromising growth performance and egg production. However, MNM has a high residual oil content which may impact metabolic health. The effects of MNM on hepatic lipid content and general, liver and kidney health have not been determined in both broilers and layers. Accordingly, two studies were run. In the broiler study two hundred 9-days old Japanese quail were randomly allocated to five diets wherein MNM replaced SBM on a crude protein (CP) basis at $0 \%, 25 \%, 50 \%, 75 \%$ and $100 \%$, respectively, in both grower and finisher diets. In the layer study, sixty 5-weeks old Japanese maiden hens, individually housed, were randomly allocated to five-layer diets where MNM replaced SBM on a graded $\mathrm{CP}$ basis as for the broilers and fed for 8 weeks. At study termination the birds were slaughtered, blood collected and plasma harvested. Livers were excised, weighed and liver lipid content determined. Plasma surrogate markers of general health, liver and kidney function were determined. Dietary MNM had no effect $(P>0.05)$ on liver lipid content as well plasma surrogate markers of general health, liver and kidney function of the broiler quail. Dietary MNM at $75 \%$ of SBM CP significantly increased plasma phosphorus concentration of quail hens compared to that of counterparts fed control. Dietary MNM can be used in broiler and layer Japanese quail diets without risking development of fatty livers and compromising liver and kidney function.

\subsection{Introduction}

Japanese quail meat and eggs are an important source of protein for human consumption (Jeke et al., 2018). Dietary protein is important for the growth and development of the human brain, especially during the early stages of life (Redoy et al., 2017). Quail products also contribute significant dietary amounts of amino acids, namely lysine, threonine, methionine, cysteine and tryptophan (Dowarah, 2013) as well as Omega- 6 and Omega-3 essential polyunsaturated fatty acids (Pereira and Vicente, 2013). These polyunsaturated fatty acids decrease the risk of developing obesity and its associated metabolic diseases (Marangoni et al., 2015).

Rearing of quail has been encouraged for socioeconomic upliftment in resource poor countries (Chadoka, 2017). Therefore, the nutritional health benefits associated with the consumption of Japanese quail meat and eggs in addition to the positive impact on livelihoods associated with rearing quail has spawned an increase in the demand for quail products. In Sub Saharan Africa (SSA) growth in human population, expansion of urban settlements and an increase in incomes fuel the demand of poultry-derived protein for human consumption (Thornton, 2010). In addition to mainstream chicken production, the introduction and tremendous uptake of Japanese quail production in SSA provides alternatives to smallholder farmers especially. When compared to the larger broiler and pullet chicken, the smaller Japanese quail require less land (space) and feed (Edris et al., 2004). Quail meat and eggs have a richer nutritional profile (Chepkemoi et al., 2017). 
Despite the "inherent" advantages associated with farming Japanese quail, high feed costs impact the cost of production. The high feed cost driven by a shortage of affordable dietary protein sources (Owen and Dike, 2013) is a major limiting factor to quail and poultry production in general (Mnisi and Mlambo, 2018). Dietary protein, the most costly feed ingredient in poultry feeds, constitutes approximately $45 \%$ of the total cost of poultry feeds (Ravindran, 2013). Soyabean meal, largely imported into SSA, is the major dietary protein source in feeds produced by the SSA poultry feed industry. To reduce dependence on the imported SBM, the search and development of locally available and more affordable dietary protein for quail feeds is critical. Research from our laboratory has recently demonstrated that MNM, an established potential source of dietary protein in feeds, can be used to replace SBM in Japanese quail broiler and layer diets without compromising growth performance, egg production meat and egg quality (Mazizi, 2020). A major short fall in the search and development of alternative feed resources for poultry production is a failure to evaluate their effects on bird welfare and health. Feed ingredients and or feed composition can promote excessive deposition of lipids in the livers of poultry (Zaman et al., 2008) increasing the risk for the development of fatty liver disease. Diet-induced excessive fat deposition in the liver of birds can lead to the development of lethal steatosis and steatohepatitis (Brunt et al., 2015). Energy dense broiler poultry finisher diets predispose birds to excessive liver fat deposition (Trott et al., 2014). At the onset of egg laying by birds, there is an increase in de novo hepatic triglyceride, phospholipid and cholesterol synthesis (Agina et al., 2017; Kaur et al., 2014; Scholtz et al., 2009) which predisposes layer-birds to fatty liver disease which can be exasperated by high energy diets (Zhang et al., 2008).

The liver is a major site of metabolism wherein hepatocyte-resident enzymes catalyse a multiplicity of metabolic reactions that are critical to the survival of cells, signal transduction and maintenance of homeostasis (Dasgupta, 2015). Damage to hepatic parenchyma tissue results in the leakage of cell contents, including hepatocyte-resident enzymes such as aspartate aminotransferase (AST) and gammaglutamyl transpeptidase (GGT) into the circulatory system (Shin et al., 2018). Metabolic waste products which are made less toxic through conjugation reactions in the liver are mostly eliminated through the kidneys in urine. There is thus synergy in the functions of the liver and kidneys in the maintenance of a desirable physiological status. Kidney malfunction manifest with an increase in the plasma concentration of metabolic waste (uric acid and urea) that are normally eliminated in urine (Scope and Schwendenwein, 2020).

In the search and development of alternative feed resources, poultry nutritionists primarily focus on the feed resources' ability to supply nutrients to support growth performance and production of quality products but tend to neglect the potential feed resource's effect on poultry welfare and health. Although we have previously demonstrated that dietary MNM can replace SBM in quail diets without compromising growth performance and egg production (Mazizi, 2020), its effects quail health has not been determined hence we evaluated its effects on the general health profile and liver and kidney health of Japanese quail. 


\subsection{Materials And Methods \\ 2.1 Study site and ethical clearance}

The study was executed at the Wits Research Animal Facility at the University of the Witwatersrand (Wits) and laboratory assays were done at the Wits School of Physiology laboratories.

\subsection{Feed ingredients and diet formulation}

Soyabean meal, yellow maize meal, feed grade limestone and wheat bran were purchased from Obaro PTY LTD, Pretoria, South Africa. The vitamin-mineral premix was procured from Trouw Nutrition (Isando, Johannesburg, South Africa). Mechanically defatted MNM was obtained from the Home of Phadima Marula Oil, a Marula processing company based in Phalaborwa, Limpopo, South Africa. The mechanically defatted MNM was further defatted with $\mathrm{n}$-hexane prior to use in feed formulation as described by Mazizi et al. (2019).

Iso-caloric and iso-nitrogenous Japanese quail grower, finisher and layer diets were formulated based on the National Research Council (NRC,1994) recommendations. The diets were formulated such that MNM replaced SBM on a CP basis, at $0 \%, 25 \%, 50 \%, 75 \%$ and $100 \%$ (diets $1,2,3,4$ and 5 , respectively). The ingredients and nutrient composition of the brooder/grower, broiler finisher and layer diets are presented in Tables 1, 2 and 3, respectively. 
Table 1

Ingredient and chemical composition of broiler brooding/grower dietary treatment

\begin{tabular}{|llllll|}
\hline Ingredients (g/kg) & Diet 1 & Diet 2 & Diet 3 & Diet 4 & Diet 5 \\
\hline Maize meal & 422.00 & 402.00 & 417.00 & 423.00 & 379.00 \\
\hline Soyabean meal & 406.00 & 318.00 & 212.00 & 108.00 & 0.00 \\
\hline Marula nut meal & 0.00 & 74.00 & 149.00 & 228.00 & 315.00 \\
\hline Wheat bran & $(0 \%)$ & $(25 \%)$ & $(50 \%)$ & $(75 \%)$ & $(100 \%)$ \\
\hline Limestone & 135.00 & 140.00 & 141.00 & 144.00 & 180.00 \\
\hline Vegetable oil & 9.00 & 9.00 & 9.00 & 10.00 & 10.00 \\
\hline DI-methionine (99\%) & 0.00 & 33.00 & 47.00 & 63.00 & 90.00 \\
\hline L-lysine HCL (98.5\%) & 2.00 & 2.00 & 2.00 & 2.00 & 2.00 \\
\hline Dicalcium phosphate & 1.00 & 3.00 & 3.00 & 3.00 & 3.00 \\
\hline Salt (NaCl) & 17.00 & 12.00 & 12.00 & 13.00 & 13.00 \\
\hline *Vit/mineral premix & 3.00 & 2.00 & 2.00 & 2.00 & 3.00 \\
\hline Total & 5.00 & 5.00 & 5.00 & 5.00 & 5.00 \\
\hline Calculated chemical composition & 1000 & 1000 & 1000 & 1000 & 1000 \\
\hline DM (\%) & & & & & \\
\hline Crude protein (\% DM) & 89.95 & 88.36 & 87.82 & 87.30 & 87.43 \\
\hline Crude fibre (\% DM) & 24.05 & 24.05 & 24.05 & 24.03 & 24.04 \\
\hline Ash (\% DM) & 3.76 & 3.64 & 3.62 & 3.57 & 3.65 \\
\hline Fat (\% DM) & 3.69 & 3.71 & 3.63 & 3.55 & 3.62 \\
\hline Neutral detergent fibre (\% DM) & 2.46 & 5.92 & 7.72 & 9.48 & 12.04 \\
\hline Acid detergent fibre (\%DM) & 14.37 & 13.53 & 13.10 & 12.56 & 12.58 \\
\hline & 4.75 & 4.17 & 3.69 & 3.19 & 2.86 \\
\hline
\end{tabular}

*Vit A: 20000000.000 IU, Vit B1 (Thiamine): 003.000g, Vit D3 (500 000): 3000000.000 IU, Vit E (500 iu): $40000.000 \mathrm{lU}$, Vit K3 (43\%): 003.000g, Vit B2 (80\%): 010.000g, Vit B6 $98 \%$ (pyrod): $005.000 \mathrm{~g}$, Vit B12 1g/kg (m):100.000mg, Niacine 99.5\%: 060.000g, Choline (Chloride 60): 606.060g, Biotine 2\%: $200.000 \mathrm{mg}$, Manganese(MnSO4-31\%):160.000g, Copper (CuSO4-25.2\%): 005.000g, Cobalt (CoSO420\%): 100.000mg, Selenium (Na2SeO3- 4.5\%): 400:000mg, Calcium pantothenate: $020.000 \mathrm{~g}$, Folic acid (96\% pure): $001.000 \mathrm{~g}$, Anty-ox Vit Dry: $100.000 \mathrm{~g}$, Zinc (Zn SO4-35\%): 090.000g, lodide (KI 76.45\%): 001.000g, Ferrous (FeSO4-30\%): $035.000 \mathrm{~g}$, Limestone powder: $2647.133 \mathrm{~g}$; DL-Methionine with purity of $99 \%$, L-Lysine HCL with purity of $98,5 \%$; Diet 1 - $0 \%$ MNM meal CP substitution of SBM CP contribution, Diet $2-25 \%$ MNM meal CP substitution of SBM CP contribution, Diet $3-50 \%$ MNM meal CP substitution of SBM CP contribution, Diet 4-75\% MNM meal CP substitution of SBM CP contribution, Diet $5-100 \%$ MNM meal CP substitution of SBM CP contribution. 


\begin{tabular}{|c|c|c|c|c|c|}
\hline Ingredients (g/kg) & Diet 1 & Diet 2 & Diet 3 & Diet 4 & Diet 5 \\
\hline Calcium (\%DM) & 0.90 & 0.89 & 0.91 & 0.90 & 0.91 \\
\hline Phosphorus (\%DM) & 0.54 & 0.56 & 0.57 & 0.57 & 0.57 \\
\hline Sodium (\%DM) & 0.16 & 0.16 & 0.16 & 0.16 & 0.16 \\
\hline Chloride (\%DM) & 0.27 & 0.17 & 0.17 & 0.27 & 0.27 \\
\hline Methionine (\%DM) & 0.54 & 0.52 & 0.54 & 0.52 & 0.54 \\
\hline Lysine (\%DM) & 1.37 & 1.37 & 1.37 & 1.37 & 1.37 \\
\hline Metabolisable energy (MJ/kg DM) & 16.27 & 16.62 & 16.88 & 16.97 & 17.03 \\
\hline \multicolumn{6}{|c|}{ 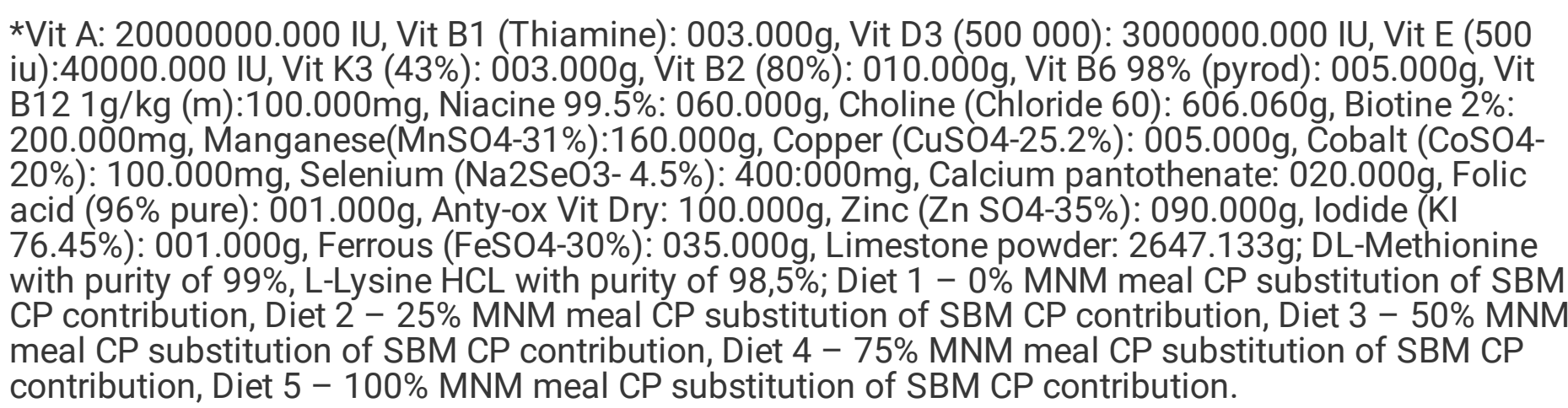 } \\
\hline
\end{tabular}


Table 2

Ingredient and chemical composition of broiler finisher dietary treatments

\begin{tabular}{|llllll|}
\hline Ingredients (g/kg) & Diet 1 & Diet 2 & Diet 3 & Diet 4 & Diet 5 \\
\hline Maize meal & 560.60 & 554.80 & 566.00 & 606.20 & 607.80 \\
\hline Soyabean meal & 327.00 & 246.50 & 165.00 & 82.90 & 0.00 \\
\hline Marula nut meal & 0.00 & 57.80 & 115.00 & 173.80 & 233.00 \\
\hline Wheat bran & $(0 \%)$ & $(25 \%)$ & $(50 \%)$ & $(75 \%)$ & $(100 \%)$ \\
\hline Limestone & 79.40 & 103.60 & 113.10 & 94.70 & 114.00 \\
\hline DI-methionine (99\%) & 18.70 & 20.30 & 20.30 & 20.80 & 20.90 \\
\hline L-lysine HCL (98.5\%) & 2.10 & 2.80 & 3.00 & 3.50 & 4.00 \\
\hline Dicalcium phosphate & 2.00 & 4.70 & 6.00 & 9.50 & 11.70 \\
\hline Salt (NaCl) & 1.90 & 9.00 & 9.00 & 0.00 & 0.00 \\
\hline *Vit/mineral premix & 3.60 & 3.80 & 3.80 & 3.80 & 3.80 \\
\hline Total & 4.70 & 4.80 & 4.80 & 4.80 & 4.80 \\
\hline Calculated chemical composition & 1000 & 1000 & 1000 & 1000 & 1000 \\
\hline Dry matter (\% DM) & & & & & \\
\hline Crude protein (\% DM) & 88.27 & 87.61 & 87.50 & 87.28 & 87.09 \\
\hline Crude fibre (\% DM) & 20.04 & 20.57 & 21.02 & 21.25 & 21.79 \\
\hline Ash (\% DM) & 3.15 & 3.30 & 3.38 & 3.26 & 3.39 \\
\hline Fat (\% DM) & 3.33 & 3.31 & 3.30 & 3.19 & 3.22 \\
\hline Neutral detergent fibre (\% DM) & 2.59 & 2.94 & 3.33 & 3.71 & 4.09 \\
\hline Acid detergent fibre (\% DM) & 12.20 & 12.59 & 12.66 & 11.89 & 12.22 \\
\hline & 3.93 & 3.78 & 3.53 & 3.03 & 2.86 \\
\hline
\end{tabular}

*Vit A: $20000000.000 \mathrm{IU}$, Vit $\mathrm{B}_{1}$ (Thiamine): 003.000g, Vit $\mathrm{D}_{3}$ (500 000): 3000000.000 IU, Vit $\mathrm{E}(500$ iu): $40000.000 \mathrm{IU}$, Vit $\mathrm{K}_{3}(43 \%): 003.000 \mathrm{~g}$, Vit $\mathrm{B}_{2}(80 \%): 010.000 \mathrm{~g}$, Vit $\mathrm{B}_{6} 98 \%$ (pyrod): $005.000 \mathrm{~g}$, Vit $\mathrm{B}_{12}$ 1g/kg (m):100.000mg, Niacine 99.5\%: $060.000 \mathrm{~g}$, Choline (Chloride 60): $606.060 \mathrm{~g}$, Biotine $2 \%$ :

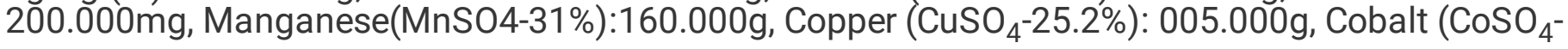
20\%): $100.000 \mathrm{mg}$, Selenium ( $\mathrm{Na}_{2} \mathrm{SeO}_{3}-4.5 \%$ ): $400: 000 \mathrm{mg}$, Calcium pantothenate: $020.000 \mathrm{~g}$, Folic

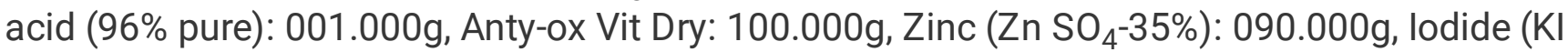
76.45\%): 001.000g, Ferrous ( $\mathrm{FeSO}_{4}-30 \%$ ): $035.000 \mathrm{~g}$, Limestone powder: $2647.133 \mathrm{~g}$; DL-Methionine with purity of $99 \%$, L-Lysine HCL with purity of $98,5 \%$; Diet $1-0 \%$ MNM meal CP substitution of SBM CP contribution, Diet $2-25 \%$ MNM meal CP substitution of SBM CP contribution, Diet $3-50 \%$ MNM meal CP substitution of SBM CP contribution, Diet 4-75\% MNM meal CP substitution of SBM CP contribution, Diet $5-100 \%$ MNM meal CP substitution of SBM CP contribution. 


\begin{tabular}{|c|c|c|c|c|c|}
\hline Ingredients (g/kg) & Diet 1 & Diet 2 & Diet 3 & Diet 4 & Diet 5 \\
\hline Calcium (\%DM) & 0.81 & 0.83 & 0.82 & 0.80 & 0.80 \\
\hline Phosphorus (\%DM) & 0.38 & 0.41 & 0.45 & 0.48 & 0.52 \\
\hline Sodium (\%DM) & 0.14 & 0.14 & 0.14 & 0.14 & 0.14 \\
\hline Chloride (\%DM) & 0.25 & 0.26 & 0.26 & 0.25 & 0.25 \\
\hline Methionine (\%DM) & 0.52 & 0.53 & 0.50 & 0.50 & 0.50 \\
\hline Lysine (\%DM) & 1.28 & 1.32 & 1.30 & 1.32 & 1.30 \\
\hline Metabolisable energy (MJ/kg DM) & 15.67 & 15.62 & 15.66 & 15.68 & 15.72 \\
\hline \multicolumn{6}{|c|}{ 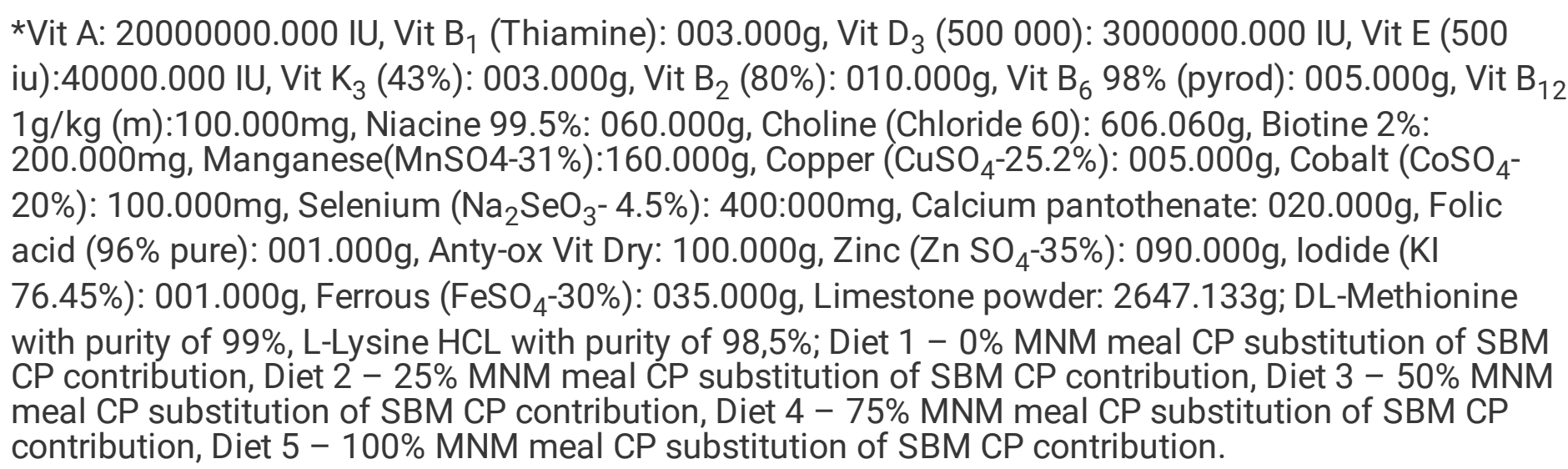 } \\
\hline
\end{tabular}


Table 3

Ingredient and chemical composition of Japanese quail layer dietary treatment

\begin{tabular}{|llllll|}
\hline Ingredients (g/kg) & Diet 1 & Diet 2 & Diet 3 & Diet 4 & Diet 5 \\
\hline Maize Meal & 411.40 & 428.60 & 457.70 & 475.30 & 548.40 \\
\hline SBM (45\%) & 391.80 & 299.00 & 199.00 & 101.10 & 0.00 \\
\hline Marula Nut Meal & 0.00 & 69.90 & 139.60 & 212.70 & 279.60 \\
\hline Wheat Bran & $(0 \%)$ & $(25 \%)$ & $(50 \%)$ & $(75 \%)$ & $(100 \%)$ \\
\hline Limestone & 88.10 & 89.70 & 89.60 & 91.00 & 49.90 \\
\hline DL-Methionine, 99\% & 93.00 & 94.70 & 94.50 & 96.10 & 94.70 \\
\hline L-Lysine HCL, 98.5\% & 2.00 & 2.60 & 3.30 & 4.00 & 4.50 \\
\hline Dicalcium Phosphate & 1.00 & 3.10 & 5.00 & 8.10 & 11.00 \\
\hline Salt (NaCl) & 2.90 & 2.50 & 1.40 & 1.50 & 2.00 \\
\hline *Vit/Mineral premix & 4.90 & 5.00 & 5.00 & 5.10 & 5.00 \\
\hline Total & 4.90 & 5.00 & 5.00 & 5.10 & 5.00 \\
\hline Calculated chemical composition & 1000 & 1000 & 1000 & 1000 & 1000 \\
\hline Dry matter (DM \%) & & & & & \\
\hline Crude protein (DM \%) & 84.55 & 83.16 & 83.36 & 82.12 & 83.53 \\
\hline Crude fibre (DM \%) & 20.82 & 21.10 & 21.51 & 21.87 & 22.16 \\
\hline Ash (DM \%) & 2.99 & 2.97 & 2.99 & 2.98 & 2.77 \\
\hline Fat (DM \%) & 3.51 & 3.40 & 3.36 & 3.29 & 3.13 \\
\hline Neutral detergent fibre (DM \%) & 2.07 & 2.46 & 2.92 & 3.31 & 3.82 \\
\hline Acid detergent fibre (DM \%) & 11.24 & 10.87 & 10.69 & 10.32 & 9.15 \\
\hline & 3.76 & 3.35 & 2.98 & 2.56 & 1.89 \\
\hline
\end{tabular}

*Vit A: $20000000.000 \mathrm{IU}$, Vit $B_{1}$ (Thiamine): 003.000g, Vit $\mathrm{D}_{3}$ (500 000): 3000000.000 IU, Vit $\mathrm{E}$ (500 iu): $40000.000 \mathrm{IU}$, Vit $K_{3}(43 \%): 003.000 \mathrm{~g}$, Vit $\mathrm{B}_{2}(80 \%): 010.000 \mathrm{~g}$, Vit $\mathrm{B}_{6} 98 \%$ (pyrod): 005.000g, Vit $\mathrm{B}_{12}$ 1g/kg (m):100.000mg, Niacine 99.5\%: 060.000g, Choline (Chloride 60): 606.060g, Biotine $2 \%$ :

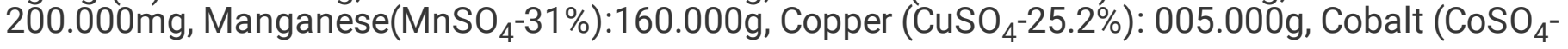
20\%): $100.000 \mathrm{mg}$, Selenium ( $\mathrm{Na}_{2} \mathrm{SeO}_{3}-4.5 \%$ ): $400: 000 \mathrm{mg}$, Calcium pantothenate: $020.000 \mathrm{~g}$, Folic

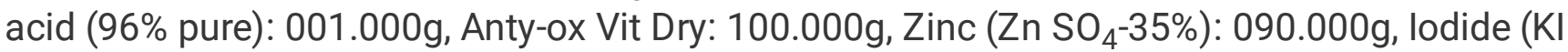
76.45\%): 001.000g, Ferrous ( $\mathrm{FeSO}_{4}-30 \%$ ): $035.000 \mathrm{~g}$, Limestone powder: $2647.133 \mathrm{~g}$; DL-Methionine with purity of $99 \%$, L-Lysine HCL with purity of $98,5 \%$; Diet $1-0 \%$ MNM meal CP substitution of SBM CP contribution, Diet $2-25 \%$ MNM meal CP substitution of SBM CP contribution, Diet $3-50 \%$ MNM meal CP substitution of SBM CP contribution, Diet 4-75\% MNM meal CP substitution of SBM CP contribution, Diet $5-100 \%$ MNM meal CP substitution of SBM CP contribution. 


\begin{tabular}{|c|c|c|c|c|c|}
\hline Ingredients (g/kg) & Diet 1 & Diet 2 & Diet 3 & Diet 4 & Diet 5 \\
\hline Calcium (DM \%) & 3.23 & 3.21 & 3.17 & 3.16 & 3.16 \\
\hline Phosphorus (DM \%) & 0.39 & 0.42 & 0.45 & 0.50 & 0.56 \\
\hline Sodium (DM \%) & 0.18 & 0.18 & 0.18 & 0.18 & 0.17 \\
\hline Chloride (DM \%) & 0.30 & 0.30 & 0.30 & 0.30 & 0.30 \\
\hline Methionine (DM \%) & 0.50 & 0.49 & 0.50 & 0.51 & 0.50 \\
\hline Lysine (DM \%) & 1.28 & 1.21 & 1.12 & 1.13 & 1.13 \\
\hline Metabolisable energy (MJ/kg DM) & 13.87 & 13.71 & 13.83 & 13.68 & 13.95 \\
\hline \multicolumn{6}{|c|}{ 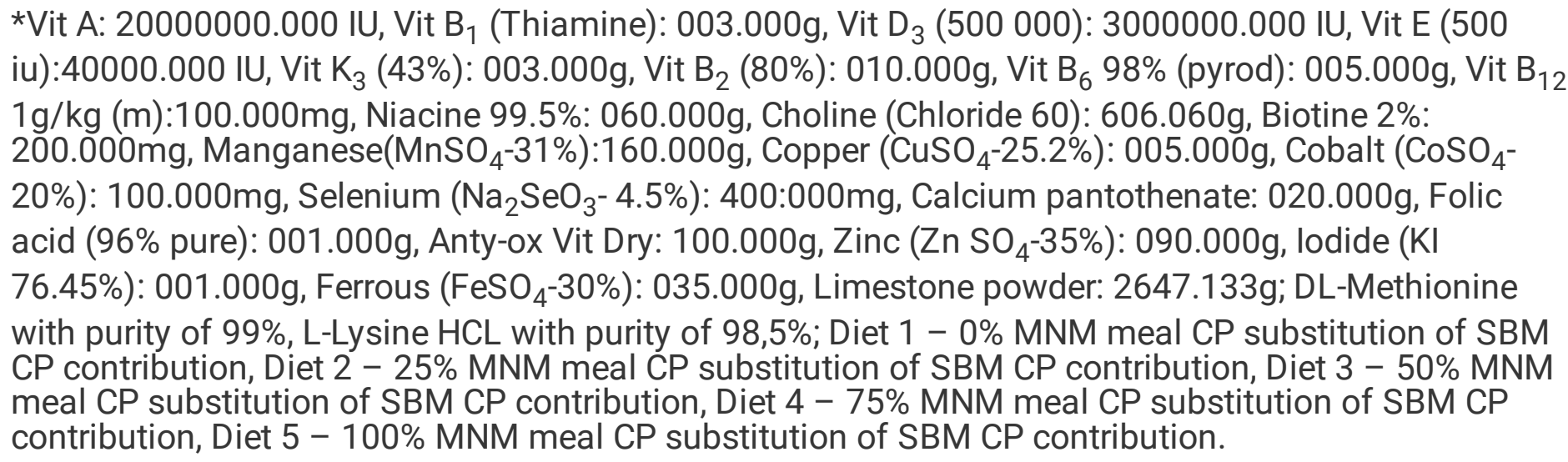 } \\
\hline
\end{tabular}

\subsection{Management of the quail}

\subsubsection{Broiler quail experiment}

The 7-day old Japanese quail chicks procured from SA Quail Breeders, East London, South Africa were habituated for 2 days during which time they were dewormed with piperazine (Kyron Laboratories Pvt Ltd, Johannesburg, South Africa) given at $90 \mathrm{mg} / \mathrm{L}$ in drinking water. The chicks housed in pens, each measuring $1.7 \mathrm{~m} \times 1.1 \mathrm{~m} \times 1.3 \mathrm{~m}$, were kept in a deep litter system. Each pen was equipped with a feeding and water trough. Infra-red lights provided supplementary heat. Feed and clean drinking water were provided ad libitum. Lights were switched on at $07 \mathrm{~h} 00$ and off at $19 \mathrm{~h} 00$. Bedding, made from clean dry wheat straw, was changed twice a week. The quail were fed the brooder/grower diets for 4 weeks and then transferred onto corresponding finisher diets and fed for 2 weeks.

\subsubsection{Layer quail experiment}

Sixty 5-week-old point of lay maiden Japanese quail hens were procured from the same supplier and habituated in the same manner as the broiler chicks. The hens were each individually housed in cages $(0.60 \times 0.60 \times 0.80 \mathrm{~m})$ equipped with a feed and water trough. The cages were contiguous and had metal grid mesh for partitions which allowed the birds to visualize each other for socialization. The feed, water and lighting were also provided in the same manner as those of the broilers described above. However, the hens were fed layer diets for 8 weeks. 


\subsection{Study design}

In the broiler experiment two hundred 9-day old Japanese quail chicks were randomly allocated to and fed grower diets wherein MNM replaced SBM on a CP basis at $0 \%, 25 \%, 50 \%, 75 \%$ and $100 \%$., for diets 1 through to 5 , respectively. The broiler quail were then fed on the respective grower diets for 4 weeks (Table 1) and then transferred onto corresponding finisher diets and fed for two weeks (Table 2). The birds were randomly allocated to the diets such that each dietary treatment was replicated 4 times with 10 chicks in a pen constituting a replicate. In the layer study, sixty 5-weeks old layer quail hens, each individually housed in a cage, were randomly allocated to and fed the respective layer diets wherein MNM substituted SBM on a CP basis at $0 \%, 25 \%, 50 \%, 75 \%$ and $100 \%$ (Table 3 ).

\subsection{Terminal procedures and sample collection}

Terminally the quail were fasted, but with access to drinking water, for $4 \mathrm{~h}$ before slaughter in order to reduce the risk of carcass contamination by gut contents (Genchev and Mihaylov, 2008). In the broiler study twenty-four broiler birds ( $n=12$ males and $n=12$ females) from each dietary treatment were randomly selected for slaughter but for the layer study all 60 hens were slaughtered by decapitation. Blood was collected into heparinised blood collection tubes and then centrifuged in a Thermo Sorvall ${ }^{\circledR}$ MC $12 \mathrm{~V}$ centrifuge (Du Pont Instruments, Connecticut, USA) at room temperature for $15 \mathrm{~min}$ at a force of $5000 \times \mathrm{g}$. A pipette (20-200 $\mathrm{L}$ Pipetman, Gilson, France) was used to transfer the plasma from each tube into $1.5 \mathrm{ml}$ microtubes (Greiner Bio-One $\mathrm{GmbH}$, Frickenhausen, Germany). The plasma samples were immediately stored in a freezer at $-20^{\circ} \mathrm{C}$ pending determination of the surrogate markers of health. After slaughter a midline incision was made and livers were excised and frozen-stored at $-20^{\circ} \mathrm{C}$ pending the determination of liver lipid content.

\subsection{Metabolic substrates and markers of liver and kidney health}

The plasma from the broiler Japanese quail was used for the determination of plasma albumin, globulin, total protein, calcium, phosphorus, cholesterol, bilirubin and uric acid concentration and AST, GGT and aamylase activities. Plasma harvested from layer Japanese quail was used to determine their plasma uric acid, calcium and phosphorus concentration. An IDEXX colorimetric-based clinical chemistry analyzer (IDEXX VetTest ${ }^{\circledR}$ Clinical Chemistry Analyser, IDEXX Laboratories Inc., USA) was used to determine the quails' plasma metabolic substrates concentration and markers of liver and kidney function as per the manufacturer's instructions.

\subsection{Liver lipid content}

The liver lipid content was determined as described by Bligh and Dyer (1959). Briefly, approximately $5 \mathrm{~g}$ of the liver sample was steeped in $150 \mathrm{ml}$ of 2:1 chloroform: methanol solution overnight in a refrigerator at $4^{\circ} \mathrm{C}$. Following the overnight steeping, each mixture was then filtered through Whatmann filter paper (Whatmann ${ }^{\circledR}$, No 1, size $185 \mathrm{~mm}$, pore size $7-11 \mu \mathrm{m}$ ) into a $250 \mathrm{ml}$ separation funnel. Thirty millilitres of $0.9 \%$ saline was then added to each filtrate, mixed and allowed to stand in a refrigerator at $4^{\circ} \mathrm{C}$ overnight 
during which time the mixture separated into two phases. The chloroform bottom phase was then collected and reduced to dryness under vacuum at $37^{\circ} \mathrm{C}$ using a rota-evaporator (Labex ${ }^{\circledR}$, Krugersdorp, South Africa) and then made up to $20 \mathrm{ml}$ with chloroform. A $2 \mathrm{ml}$ extract aliquot was then placed into a dried, pre-weighed vial, dried at $50^{\circ} \mathrm{C}$ for 30 -min in an oven (Salvis ${ }^{\circledR}$, Salvis Lab, Switzerland), cooled in a desiccator and reweighed to determine the lipid content. The liver lipid content was computed based on the liver weight using the following equation:

liver lipid content $(\%)=\frac{\text { weightofoil }(g)}{\text { weightofoilandliver }(g)} \times 100$

\subsection{Statistical Analysis}

Data are presented as mean \pm SD. GraphPad Prism 5 software (GraphPad Software, San Diego, California, USA) was used to analyse data. Parametric data on liver lipid content, circulating metabolic substrates concentration and markers of liver and kidney function were analysed using a one-way ANOVA. Treatment means were compared using Tukey's post hoc test. Significance was set at $P<0.05$.

\subsection{Results}

Figure $1 \mathrm{~A}$ and B show the effect of dietary MNM on liver lipid content of male and female broiler quail, respectively and Figure $1 \mathrm{C}$ shows the meal's effect on the liver lipid content of layer Japanese quail hens. In both broiler and layer Japanese quail, dietary MNM had no effect $(P>0.05)$ on liver lipid content. Table 4 below shows the effect of dietary MNM on circulating metabolic substrates content and markers of liver and kidney function of broiler Japanese quail while Table 5 shows the meal's effects on plasma calcium, phosphorus and uric acid concentration of layer Japanese quail. Dietary treatments had no significant effect $(P>0.05)$ on the surrogate markers of liver and kidney function as well as the general health of broiler quail and on plasma calcium and uric acid concentration of layer Japanese quail. However dietary MNM significantly increased the plasma phosphorus concentration of layer quail hens fed diet 4 compared to that of counterparts fed diet $1(P<0.05)$. 
Table 4

Effect of graded dietary substitution of soyabean meal with Marula nut meal on plasma profile of surrogate markers of general health of broiler Japanese quail

\begin{tabular}{|lllllll|}
\hline Parameter & Diet 1 & Diet 2 & Diet 3 & Diet 4 & Diet 5 & Significance \\
level
\end{tabular}


Table 5

Effect graded dietary substitution of soybean meal with Marula nut meal on plasma calcium, phosphorus and uric acid concentration of the layer Japanese quail

\begin{tabular}{|c|c|c|c|c|c|c|}
\hline Parameter & Diet 1 & Diet 2 & Diet 3 & Diet 4 & Diet 5 & $\begin{array}{l}\text { Significance } \\
\text { level }\end{array}$ \\
\hline $\begin{array}{l}\text { Calcium } \\
\text { (mmol/L) }\end{array}$ & $\begin{array}{l}3.76 \pm \\
0.24^{\mathrm{a}}\end{array}$ & $\begin{array}{l}4.00 \pm \\
0.00^{\mathrm{a}}\end{array}$ & $\begin{array}{l}3.74 \pm \\
0.24^{\mathrm{a}}\end{array}$ & $\begin{array}{l}4.00 \pm \\
0.00^{\mathrm{a}}\end{array}$ & $\begin{array}{l}4.00 \pm \\
0.00^{\mathrm{a}}\end{array}$ & ns \\
\hline $\begin{array}{l}\text { Phosphate } \\
\text { (mmol/L) }\end{array}$ & $\begin{array}{l}2.23 \pm \\
0.71^{\mathrm{a}}\end{array}$ & $\begin{array}{l}4.29 \pm \\
0.94^{\mathrm{ab}}\end{array}$ & $\begin{array}{l}3.68 \pm \\
1.80^{\mathrm{ab}}\end{array}$ & $\begin{array}{l}4.66 \pm \\
1.07^{\mathrm{b}}\end{array}$ & $\begin{array}{l}3.14 \pm \\
1.65^{\mathrm{ab}}\end{array}$ & * \\
\hline $\begin{array}{l}\text { Uric acid } \\
(\mu \mathrm{mol} / \mathrm{L})\end{array}$ & $\begin{array}{l}440.20 \pm \\
46.15^{a}\end{array}$ & $\begin{array}{l}502.60 \pm \\
80.72^{\mathrm{a}}\end{array}$ & $\begin{array}{l}418.30 \pm \\
59.69^{a}\end{array}$ & $\begin{array}{l}405.50 \pm \\
52.92^{\mathrm{a}}\end{array}$ & $\begin{array}{l}355.70 \pm \\
27.41^{\mathrm{a}}\end{array}$ & ns \\
\hline \multicolumn{7}{|c|}{$\begin{array}{l}\text { ns = not significant, } \mathrm{P}>0.05, * \mathrm{P}<0.05 \text {; ab Within row means with different superscripts are } \\
\text { significantly different at } \mathrm{P}<0.05 \text {. The plasma phosphate concentration of quail hens fed diet } 4 \text { was } \\
\text { significantly higher }(\mathrm{P}<0.05 \text { ) compared to that of hens fed diet } 1 \text {. The plasma calcium and uric acid } \\
\text { concentration were similar across dietary treatments. Diet } 1-0 \% \text { inclusion of MNM (control), Diet } 2- \\
25 \% \text { MNM inclusion on crude protein }(C P) \text { basis, Diet } 3-50 \% \text { MNM inclusion on CP basis, Diet } 4- \\
75 \% \text { MNM inclusion on CP basis, Diet } 5-100 \% \text { MNM inclusion on CP basis; Data presented as mean } \pm \\
\text { SD; } n=12 \text { birds. }\end{array}$} \\
\hline
\end{tabular}

\subsection{Discussion}

Carbohydrates and protein, major dietary constituents, when consumed in excess amounts are metabolised to lipogenic carbon skeletons which are used to accrete fat in the liver (Jaya Putra et al., 2015; Enes et al., 2011) causing increased liver fat content. In addition to diet-induced impacts on liver fat content, the birds' physiological status also impacts liver lipid content: for example, the onset of egg laying is associated with increased de novo hepatic triglyceride, phospholipid and cholesterol synthesis (Agina et al., 2017; Kaur et al., 2014; Scholtz et al., 2009). Dietary and or physiological status induced excessive liver lipid accretion predisposes birds to increased risk of developing fatty liver disease (Fong et al., 2000; Parry and Hodson, 2017). It has been shown that laying hens with liver lipid content ranging from $40-70 \%$ are prone to suffer with fatty liver disease (Shini and Bryden, 2009) which leads to steatosis and steatohepatitis (Ayala et al., 2009) and may cause liver failure. In Japanese quail kept for meat, it has been reported that their liver lipid content ranged from $9.83-29 \%$ and $8.53-35 \%$ for males and females, respectively (Kystsiv et al., 2010; Maeda et al., 1986). In our study we show that in male and female broiler quail the liver total lipid content ranged from $9.54 \%-20.90 \%$ and $10.82 \%-24.24 \%$, respectively and that of layer quail ranged from $3.94 \%-8.33 \%$. These findings demonstrate that the level of liver lipid content in both broiler and layer quail was within the range of liver lipid content in adult male and female quail previously reported (Kystsiv et al., 2010; Maeda et al., 1986). Importantly, our findings suggest that MNM can be used as a dietary protein in Japanese quail feeds for quail kept for meat and egg production without risk of causing increased liver lipid accretion. Dietary lipid content and profile is mirrored in poultry products (Bostami et al., 2017). Due to the higher residual oil in the MNM used to formulate the test diets compared to that of SBM, we expected the livers of quail fed MNM-based diets to 
contain higher hepatic lipid content. This "mismatch" suggests that in addition to MNM use not mediating increased liver lipid content, its use seems to decrease liver lipid content in Japanese quail. Maurice et al. (1979) contends that laying hens are more susceptible to the development of fatty liver. Our findings show that the liver lipid content of the quail hens ranged from 4.4-7.4\% which is within the range of liver lipid content in adult quail fed a cereal-based diet as reported Maurice and Jensen (1978).

Antinutritional factors in some plant-derived feed ingredients, for example, tannins, phytates, oxalates, saponins, lectins and alkaloids are known to poison and damage liver cells (Gemede and Ratta, 2014). We show that dietary MNM had no effect on plasma AST and GGT activities of the quail neither did it affect plasma cholesterol and urea concentration of the quail. While our reported AST activities are higher than those reported by Agina et al. (2017) in younger Japanese quail, we contend that the seemingly abnormally high plasma AST activity we observed could have been due to other AST activity coming from monocytes and erythrocytes as these cells are known to contribute to plasma AST activity especially when haemolysis occurs (Bovera et al., 2015; Sokół et al., 2015). In the current study, the assay for AST did not differentiate between the different AST isoforms, thus it cannot be categorically stated that the observed AST activity is of hepatic origin only. Scholtz et al. (2009) reported plasma GGT activities of $1.7 \pm 0.2 \mathrm{U} / \mathrm{L}$ and $1.9 \pm 0.1 \mathrm{U} / \mathrm{L}$ in adult male and female quail, respectively. The plasma GGT activities of both male and female quail from our study fall within the range reported by Scholtz et al. (2009). Gamma-glutamyltransferase is found in the cell membranes of bile duct cells and it is a more specific indicator of liver damage in birds (Ognik and Krauze, 2016). We thus infer that dietary MNM did not elicit liver damage in the quail.

The liver metabolises cholesterol to bile acids and bile salts which when bile is released into the duodenum emulsifies fat. The plasma cholesterol in adult quail has been reported to range from 4.24 $\mathrm{mmol} / \mathrm{L}$ to $11.81 \mathrm{mmol} / \mathrm{L}$ (Abou-Kassem et al., 2019; Agina et al., 2017; Ali et al., 2012). These reported plasma cholesterol concentrations are within range of those we report (range: $4.29 \pm 0.55$ to $5.42 \pm 0.55$ $\mathrm{mmol} / \mathrm{L}$ ) in our findings suggesting that the MNM did not alter cholesterol metabolism in the quail. The liver also synthesizes plasma proteins including among others albumin and globulins. We show similarities in plasma cholesterol, albumin, globulin and total protein in broiler and layer quail across dietary treatments suggesting that dietary MNM did not compromise the liver's synthetic and detoxification function.

The kidneys play a major role in the excretion of metabolic wastes (Onopiuk et al., 2015). They synthesise chemical messengers; erythropoietin and renin (Kurtz, 2017) and also activate vitamin $D_{2}$ to active calcitriol (Murabito and Hallmark, 2018). Furthermore, they play a vital in the maintenance of body fluid and electrolyte balance (Reece et al., 2015). Antinutritional factors in feed ingredients and feed-borne toxins can compromise kidney function (Echols, 2006; Siller, 1981) precipitating both kidney damage and failure. Although glomerular filtration rate is the gold standard of evaluating kidney health (Levey and Inker, 2017), surrogate markers among them plasma blood urea and uric acid concentration (Giordano et al., 2015) can be used. When kidney function is compromised, excretory role is compromised and manifests with an increase in the blood of metabolic wastes including among others urea and uric acid 
which are normally removed from the body in urine. We report similarities in the quail's plasma urea and uric acid concentration across dietary treatments showing that dietary MNM did not compromise the kidneys' excretory role.

Calcium and phosphorus are constituents of eggshells and must be supplied in adequate quantities during the egg-laying (Vries et al., 2010; Rodrigues et al., 2013). Their plasma concentration increases when birds start laying (Kashap et al., 2017; Albokhadaim et al., 2012). These macrominerals are critical to maintenance of normal bone health (Gaffney-Stomberg, 2019). Onset of eggshell formation decreases plasma calcium concentration which then stimulates parathyroid hormone-mediated bone resorption in order to maintain calcium homeostasis (Berto et al., 2009). Phytates and oxalates in some plant-derived feed resources chelate calcium decreasing its absorption from the small intestines which can compromise bone health and eggshell quality (Summers et al., 1992). Our layer study show similarities in the plasma calcium concentration of the quail hens across dietary treatments albeit quail hen fed diet 4 had higher plasma phosphate concentration compared to counterparts fed the control diet. The plasma calcium-phosphate balance is maintained by three key processes: absorption from the small intestines, reabsorption and excretion by kidneys and deposition and mobilisation of bone (Li et al., 2018). While it might be difficult to pinpoint exact cause of the higher plasma phosphorus concentration in layer quail fed diet 4 1, dietary MNM did not affect the layer quail's plasma calcium concentration suggesting that it may not have affected calcium metabolism in the layer quail. There is need however for future studies to consider the impact of the diets on bone mineralisation.

\subsection{Conclusion}

Marula nut meal can be used to replace SBM as a dietary protein source in Japanese quail reared for meat and or egg production without the risk of causing fatty liver disease and or kidney and liver damage.

\section{Declarations}

\section{Author contribution}

BEM, KHE and EC conceived and designed the study. BEM performed the experiments, analyzed the data and wrote the manuscript. KHE and EC reviewed and corrected the manuscript. All authors read and approved the manuscript.

\section{Acknowledgements}

We thank the National Research Foundation of South Africa (grant number 105289) for funding this study and we acknowledge the Wits Research Animal Facility staff at the University of the Witwatersrand for assisting with animal care.

\section{Conflict of interest}


No potential conflict of interest is reported by the authors.

\section{Ethical statement}

The University of the Witwatersrand's Animal Ethics Screening Committee approved the study (Ethics approval certificate number: 2017/08/54B).

\section{Data availability}

The datasets used and analyzed during the current study are available from the corresponding author on reasonable request.

\section{References}

1. Agina, O.A., Ezema, W.S., Iwuoha, E.M., 2017. The Haematology and Serum Biochemistry Profile of Adult Japanese Quail (Coturnix coturnix japonica). Notulae Scientia Biologicae. 9(1), 67-72.

2. Albokhadaim, I., Althnaian, T., El-Bahr, S.M.,2012. Investigation of selected biochemical parameters of local chickens with different age and sex in Al-ahsa, Saudi Arabia. Pakistan Journal of Biological Sciences, 15(17), 827-832.

3. Ali, M.A., Hmar, L., Devi, L.I., Prava, M., Lallianchhunga, M.C., Tolenkhomba, T.C., 2012. Effect of age on the haematological and biochemical profile of Japanese quails (Coturnix coturnix japonica). International Multidisciplinary Research Journal, 2(8), 32-35.

4. Attia-Ismail, S.A., 2015. Plant Secondary metabolites: Deleterious Effects, Remediation. In: Öztürk M., Ashraf M., Aksoy A., Ahmad M., Hakeem K. Plants, Pollutants and Remediation, 157-178. (Springer, Dordrecht).

5. Ayala, I., Castillo, A.M., Adanez, G., Fernandez-Rufete, A., Pérez, B.G., Castells, M.T., 2009. Hyperlipidemic chicken as a model of non-alcoholic steatohepatitis. Experimental Biology and Medicine, 234(1),10-16.

6. Berto, D., Molino, A., Vercese, F., Pelicia, K., Silva, A., Faitarone, A., Garcia, E., 2009. Calcium and available phosphorus levels for laying hens in second production cycle. Revista Brasileira de Ciência Avícola, 11(1), 39-49.

7. Bligh, E.G., Dyer, W.J., 1959. A rapid method of total lipid extraction and purification. Canadian Journal of Biochemistry and Physiology, 37(1), 911-917.

8. Bostami, A.B.M.R, Mun, H.S, Yang, C.J., 2017. Breast and Thigh Meat Chemical Composition and Fatty Acid Profile in Broilers Fed Diet with Dietary Fat Sources. Journal of Food Process Technology, $8,672$.

9. Bovera, F., Piccolo, G., Gasco, L., Marono, S., Loponte, R., Vassalotti, G., Mastellone, V., Lombardi, P., Attia, Y.A., Nizza, A., 2015. Yellow mealworm larvae (Tenebrio molitor , L.) as a possible alternative to soybean meal in broiler diets. British Poultry Science, 56(5), 569-575. 
10. Brunt, E.M., Wong, V.W.S., Nobili, V., Day, C.P., Sookoian, S., Maher, J.J., Bugianesi, E., Sirlin, C.B., Neuschwander-Tetri, B.A., Rinella, M.E., 2015. Nonalcoholic fatty liver disease. Nature reviews Disease primers, 1(1), 1-22.

11. Chadoka, T., 2017. The socio economic impacts of quail farming to the local Community in Southlea Park a Harare high density suburb (Doctoral dissertation, Bindura University Of Science Education).

12. Chepkemoi, M., Macharia, J.W., Sila, D., Oyier, P., Malaki, P., Ndiema, E., Agwanda, B., Obanda, V., Ngeiywa, K.J., Lichoti, J., Ommeh, S.C., 2017. Physical characteristics and nutritional composition of meat and eggs of five poultry species in Kenya. Livestock Research for Rural Development, 29(8),111.

13. Dasgupta, A., 2015. Alcohol and its Biomarkers:Liver Enzymes as Alcohol Biomarkers.121-137.

14. Dowarah, R., 2013. The role of poultry meat and eggs in human nutrition. Poultry Line, June, 31-33.

15. Echols, M.S., 2006. Evaluating and Treating the kidneys. Clinical Avian Medicine, 2, 451-492.

16. Edris, A.M., Shaltout, F.A., Arab, W.S., 2004. Bacterial evaluation of quail Meat. Benha Veterinary Medicine Journal, 16(1),1-14.

17. Enes, P., Peres, H., Sanchez-Gurmaches, J., Navarro, I., Gutiérrez, J., Oliva-Teles, A., 2011. Insulin and IGF-I response to a glucose load in European sea bass (Dicentrarchus labrax) juveniles. Aquaculture, 315(3-4), 321-326.

18. Fong, D.G., Nehra, V., Lindor, K.D., Buchman, A.L., 2000. Metabolic and nutritional considerations in nonalcoholic fatty liver. Hepatology, 32(1), 3-10.

19. Gaffney-Stomberg, E., 2019. The Impact of Trace Minerals on Bone Metabolism. Biological Trace Element Research, 188(1), 26-34.

20. Gemede, H.F., Ratta, N., 2014. Antinutritional Factors in Plant Foods: Potential Health Benefits and Adverse Effects. International Journal of Nutrition and Food Sciences, 3(4), 284-289.

21. Genchev, A., Mihaylov, R., 2008. Slaughter analysis protocol in experiments using Japanese quails (Coturnix Japonica). Trakia Journal of Sciences, 6(4), 66-71.

22. Giordano, C., Karasik, O., King-Morris, K., Asmar, A., 2015. Uric Acid as a Marker of Kidney Disease: Review of the Current Literature. Disease Markers, 2015, 1-6.

23. Guan, Y.S., He, Q., 2015. Plants Consumption and Liver Health. Evidence-based complementary and alternative medicine,2015,1-10.

24. Jaya Putra, S., Saraswati, T., Isdadiyanto, S., 2015. Profile triglycerides Japanese quail (Coturnix coturnix japonica) after giving turmeric (Curcuma longa) powder. International Journal of Science and Engineering, 8(1), 65-68.

25. Jeke, A., Phiri, C., Chitindingu, K., Taru, P., 2018. Ethnomedicinal use and pharmacological potential of Japanese quail (Coturnix coturnix japonica) birdsmeat and eggs, and its potential implications on wild quail conservation in Zimbabwe: A review. Cogent Food \& Agriculture, 4(1),1507305.

26. Kashap, A., Ambade, R.B., Dalvi, S.H., Kapale, P.M., 2017. Study of Serum Biochemical Metabolites during Late Laying Phase of Layer Chicken. Indian Research Journal of Extension Education, 
(January), 5-9.

27. Kaur, N., Chugh, V., Gupta, A.K., 2014. Essential fatty acids as functional components of foods- a review. Journal of food science and technology, 51(10), 2289-303.

28. Kuang, H., Yang, F., Zhang, Y., Wang, T., Chen, G., 2018. The Impact of Egg Nutrient Composition and Its Consumption on Cholesterol Homeostasis. Cholesterol, 1-23.

29. Kurtz, A., 2017. Endocrine functions of the renal interstitium. Pflügers Archiv - European Journal of Physiology, 469(7-8), 869-876.

30. Kystsiv, V., Ratych, I., Borowiec, F., Kyryliv, B. and Andrejeva, L., 2010. Species peculiarities of lipid and fatty acid composition of liver and egg yolk in japanese quails and laying hens. Animal biology, (12,№ 1), 88-93.

31. Lala, V., Minter, D.A., 2019. Liver Function Tests. (StatPearls Publishing).

32. Levey, A.S. and Inker, L.A., 2017. Assessment of glomerular filtration rate in health and disease: a state of the art review. Clinical Pharmacology and Therapeutics, 102(3), 405-419.

33. Li, P., Wang, R., Jiao, H., Wang, X., Zhao, J., Lin, H., 2018. Effects of dietary phosphorus level on the expression of calcium and phosphorus transporters in laying hens. Frontiers in Physiology, 9(5), 112.

34. Maeda, Y., Okamoto, S., Hashiguchi, T.,1986. Genetic variation of liver lipid content of coturnix quail. Poultry science, 65(2), 205-208.

35. Malebana, I.M.M., Nkosi, B.D., Erlwanger, K.H., Chivandi, E., 2018, A comparison of the proximate, fibre, mineral content, amino acid and the fatty acid profile of Marula (Sclerocarya birrea caffra) nut and soyabean (Glycine max) meals. Journal of the Science of Food and Agriculture, 98(4), 13811387.

36. Marangoni, F., Corsello, G., Cricelli, C., Ferrara, N., Ghiselli, A., Lucchin, L., Poli, A., 2015. Role of poultry meat in a balanced diet aimed at maintaining health and wellbeing: an Italian consensus document. Food and Nutrition Research, 59, 27606.

37. Marzinke, M.A and Dufour, D.R, 2020. Contemporary Practice in Clinical Chemistry: Laboratory diagnosis of liver disease, 545-559.

38. Maurice, D.V., Jensen, L.S., 1978. Liver lipid deposition in caged layers as influenced by fermentation by-products and level of dietary fat. Poultry Science, 57(6), 1690-1695.

39. Maurice, D. V., Jensen, L.S., 1979. Hepatic Lipid Metabolism in Domestic Fowl as Influenced by Dietary Cereal. The Journal of Nutrition, 109(5), 872-882.

40. Mazizi, B.E., 2020. Effects of dietary Sclerocarya Birrea Caffra (Marula) Nut Meal on the growth performance, feed utilization efficiency, product quality, health status and viscera macromorphometry of broiler and layer Japanese quail, (unpublished thesis, University of the Witwatersrand)

41. Mazizi, B.E. Erlwanger, K.E, Chivandi, E., 2019. The effect of dietary Marula nut meal on the physical properties, proximate and fatty acid content of Japanese quail meat, Veterinary and Animal Science, 
(9),100096.

42. Mazizi, B.E., Moyo, D., Erlwanger, K.E, Chivandi, E., 2019. Effects of Dietary Sclerocarya Birrea Caffra (Marula) Nut Meal on the Growth Performance and Viscera Macromorphometry of Broiler Japanese Quail. The Journal of Applied Poultry Research, 28 (4), 1028-1038.

43. Mlambo, V., Dlamini, B.J., Ngwenya, M.D., Mhazo, N., Beyene, S.T., Sikosana, J.L.N.,2011. In sacco and in vivo evaluation of marula (Sclerocarya birrea) seed cake as a protein source in commercial cattle fattening diets. Livestock Research for Rural Development, 23(5),1-10.

44. Mlambo, V., Dlamini, B.J., Nkambule, M.T., Mhazo, N., Sikosana, J.L.N., 2011. Nutritional evaluation of marula (Sclerocarya birrea) seed cake as a protein supplement for goats fed grass hay. Tropical Agriculture, 88(1), 35-43.

45. Mnisi, C.M., Mlambo, V., 2018. Growth performance, haematology, serum biochemistry and meat quality characteristics of Japanese quail (Coturnix coturnix japonica) fed canola meal-based diets. Animal Nutrition, 4(1), 37-43.

46. Mthiyane, D.M.N., Mhlanga, B.S., 2017. The nutritive value of marula (Sclerocarya birrea) seed cake for broiler chickens: nutritional composition, performance, carcass characteristics and oxidative and mycotoxin status. Tropical animal health and production, 49(4), 835-842.

47. Murabito, S., Hallmark, B.F., 2018. Complications of Kidney Disease. Nursing Clinics of North America, 53(4), 579-588.

48. Mushtaq, M.M.H., Pasha, T.N., Saima, Akram, M., Mushtaq, T., Parvin, R., Farooq, U., Mehmood, S., Iqbal, K.J., Hwangbo, J., 2013. Growth Performance, Carcass Traits and Serum Mineral Chemistry as Affected by Dietary Sodium and Sodium Salts Fed to Broiler Chickens Reared under Phase Feeding System. Asian-Australasian Journal of Animal Sciences, 26(12), 1742-1752.

49. NRC (1994) Nutrient requeriments of poultry. National Academies Press.

50. Ognik, K., Krauze, M., 2016. The potential for using enzymatic assays to assess the health of turkeys. World's Poultry Science Journal, 72(03), 535-550.

51. Onopiuk, A., Tokarzewicz, A., Gorodkiewicz, E., 2015. Cystatin C: A Kidney Function Biomarker. Advances in Clinical Chemistry. 68, 57-69.

52. Otter, A., 2013. Diagnostic blood biochemistry and haematology in cattle. In Practice, 35(1), 7-16.

53. Owen, O., Dike, U., 2013. Japanese Quail (Coturnix coturnix japonica) Husbandry: A means of Increasing Animal Protein Base in Developing Countries. Journal of Environmental Issues and Agriculture in Developing Countries, 5(1), 2007-2010.

54. Parry, S.A., Hodson, L., 2017. Influence of dietary macronutrients on liver fat accumulation and metabolism. Journal of Investigative Medicine, 65(8), 1102-1115.

55. Pereira, P.M.., Vicente, A.F., 2013. Meat nutritional composition and nutritive role in the human diet. Meat Science, 93(3), 586-592.

56. Ravindran, V., 2013. Poultry feed availability and nutrition in developing countries. Poultry Development Review, 2, 60-63. 
57. Reece, W., Erickson, H., Goff, J., Uemura, E., 2015. Kidney Function in Birds. (John Wiley \& Sons, Inc.)

58. Rodrigues, E.A., Oliveira, M.C. de, Cancherini, L.C., Duarte, K.F., Santana, L.F., Junqueira, O.M., 2013. Calcium in pre-laying and laying rations on the performance and quality of laying hens' eggshell. Acta Scientiarum. Animal Sciences, 35(2), 153-157.

59. Redoy, M., Shuvo, A., Al-Mamun, M.,2017. A review on present status, problems and prospects of quail farming in Bangladesh. Bangladesh Journal of Animal Science, 46(2), 109-120.

60. Rui, L.,2014. Energy Metabolism in the Liver. In Comprehensive Physiology. (John Wiley \& Sons, Inc, USA)

61. Sakas, P.S., 2002. Understanding avian laboratory tests. Essentials of avian medicine: a guide for practitioners, 1-10.

62. Saini, R.K., Keum, Y.S., 2018. Omega-3 and omega-6 polyunsaturated fatty acids: Dietary sources, metabolism, and significance-A review. Life sciences, 203, 255-267.

63. Scholtz, N., Halle, I., Flachowsky, G., Sauerwein, H., 2009. Serum chemistry reference values in adult Japanese quail (Coturnix coturnix japonica) including sex-related differences. Poultry Science, 88(6), 1186-1190.

64. Scope, A. and Schwendenwein, I., 2020. Laboratory Evaluation of Renal Function in Birds. Veterinary Clinics: Exotic Animal Practice, 23(1), 47-58.

65. Shini, S., Bryden, W.L., 2009. Occurrence and control of fatty liver haemorrhagic syndrome (FLHS) in caged hens. A report for the Australian egg Corporation Limited. AECL Publication No UQ-105A. AECL Project No UQ-105. (July), 1448-1316.

66. Shin, S.Y., Lee, J., Gil, H.N., Jung, Y.J., Kim, G.L., Kang, G.H. and Lim, Y., 2018. Schisandra chinensis inhibiting TGF $\beta$-induced activation of hepatic stellate cells. Applied Biological Chemistry, 61(6), 607616.

67. Stern, R.A. and Mozdziak, P.E., 2019. Differential ammonia metabolism and toxicity between avian and mammalian species, and effect of ammonia on skeletal muscle: A comparative review. Journal of Animal Physiology and Animal Nutrition, 103(3),774-785.

68. Siller, W.G., 1981. Renal pathology of the fowl-A review. Avian Pathology, 10(3), 187-262.

69. Sokół, R., Gesek, M., Raś-Noryńska, M., Michalczyk, M., Koziatek, S., 2015. Biochemical parameters in Japanese quails Coturnix coturnix japonica infected with coccidia and treated with toltrazuril. Polish Journal of Veterinary Sciences, 18(1), 79-82.

70. Sturkie, P.D., Griminger, P., 1986. Body Fluids: Blood. In Avian Physiology (Springer, New York)

71. Summers, J.D., Bedford, M., Spratt, D., 1992. Sulphur and calcium supplementation of soybean and canola meal diets. Canadian Journal of Animal Science, 72(1), 127-133.

72. Thornton, P.K., 2010. Livestock production: recent trends, future prospects. Philosophical Transactions of the Royal Society B: Biological Sciences, 365(1554), 2853-2867.

73. Trott,KA., Giannitti, F., Rimoldi,G., Hill, A., Woods,L., Barr,B., Anderson, M., Mete, A., 2014. Fatty liver hemorrhagic syndrome in backyard chicken: a retrospective histopathologic case series. Veterinary 
Pathology, 51(4),787-795.

74. Vleck, C.M., 2006. Physiological Condition and Reproductive Consequences in Adelie Penguins. Integrative and Comparative Biology, 42(1), 76-83.

75. Vries, S. De, Kwakkel, R.P., Dijkstra, J., 2010. Dynamics of calcium and phosphorus metabolism in laying hens. In Phosphorus and calcium utilization and requirements in farm animals, 133-150.

76. Zaman, Q.U., Mushtaq, T., Nawaz, H., Mirza, M.A., Mahmood, S., Ahmad, T., Babar, M.E., Mushtaq, M.M.H., 2008. Effect of varying dietary energy and protein on broiler performance in hot climate. Animal Feed Science and Technology, 146(3-4),302-312.

77. Zhang, J., Chen, D. Yu, B., 2008. Effect of different dietary energy sources on induction of fatty liverhemorrhagic syndrome in laying hens. International Journal of Poultry Science, 7(12), 1232-1236.

\section{Figures}

A.

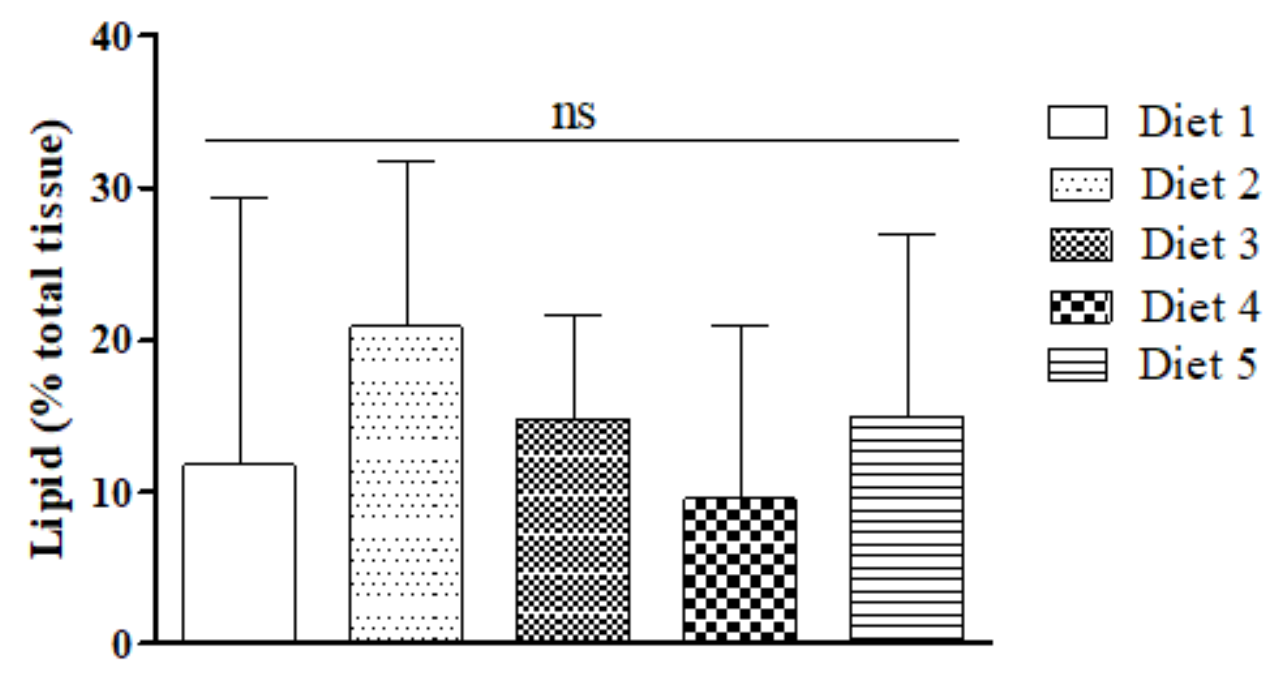

B.

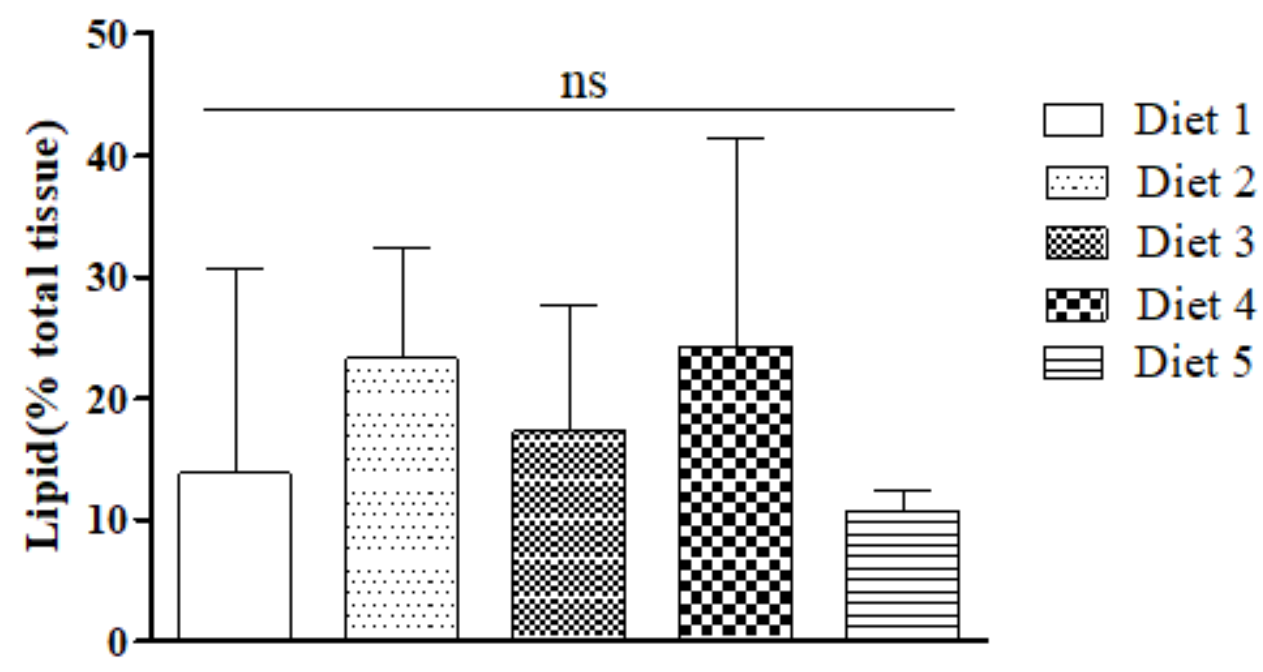




\section{Figure 1}

Effect of dietary Marula nut meal on the liver lipid content of male (A) and female (B) broiler Japanese quail

ns $=$ not significant. There were no significant differences $(P>0.05)$ the liver lipid content of male and female quail across dietary treatments. $A=$ male, $B=$ female. Diet $1-0 \%$ inclusion of MNM (control), Diet $2-25 \%$ MNM inclusion on crude protein basis, Diet $3-50 \%$ MNM inclusion on crude protein basis, Diet $4-75 \%$ MNM inclusion on crude protein basis, Diet 5-100\% MNM inclusion on crude protein basis; values expressed as mean $\pm S D ; n=12$ males and $n=12$ females.

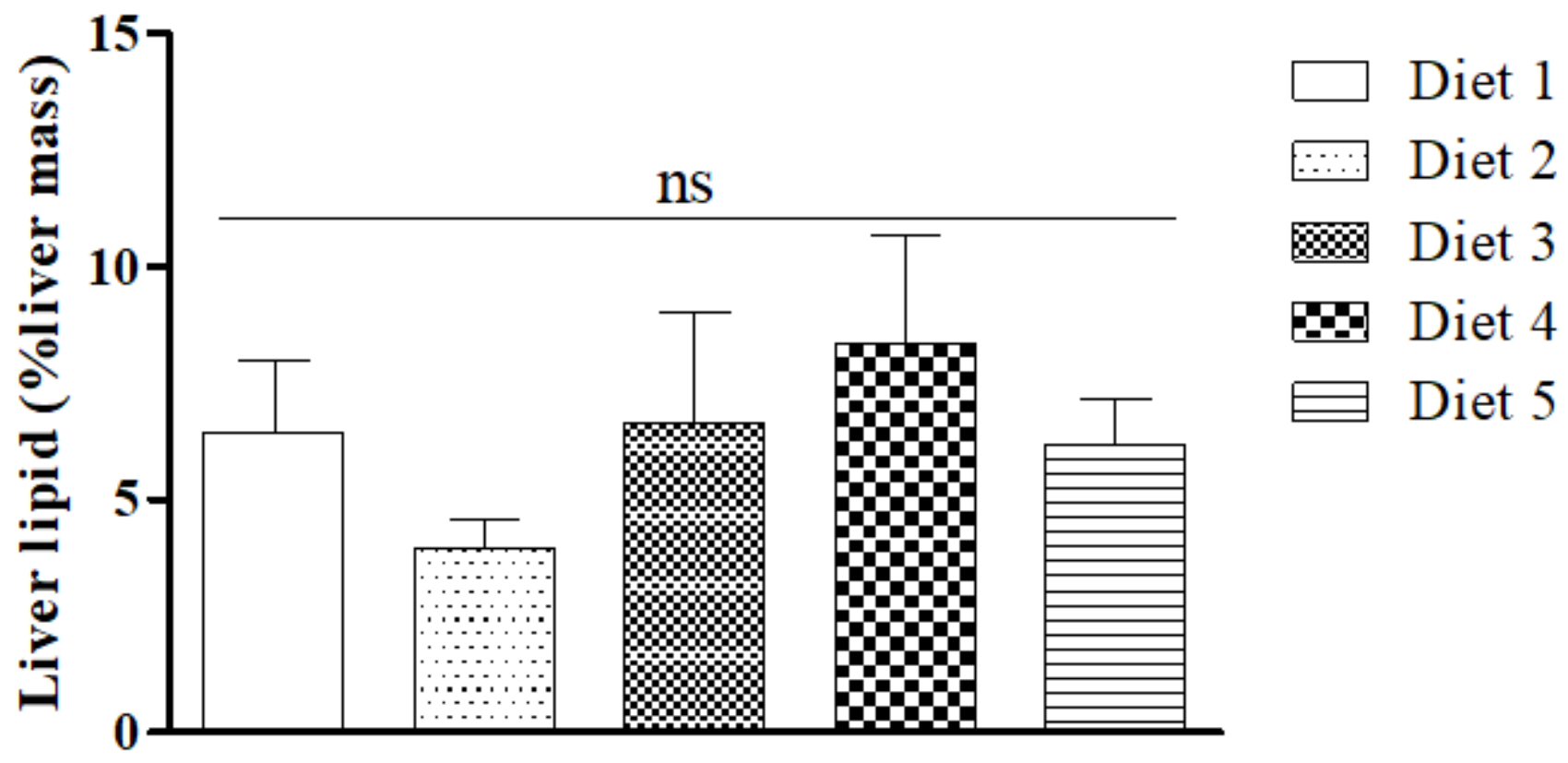

Figure 2

Effect of dietary Marula nut meal on the liver lipid content of layer Japanese quail hens.

There were no significant differences $(P>0.05)$ in the liver lipid content of the layer Japanese quail hens across the dietary treatments. Diet $1-0 \%$ inclusion of MNM (control), Diet $2-25 \%$ MNM inclusion on crude protein (CP) basis, Diet $3-50 \%$ MNM inclusion on CP basis, Diet $4-75 \%$ MNM inclusion on CP basis, Diet 5-100\% MNM inclusion on CP basis; Data presented as mean \pm SD, $n=12$ birds. 